\title{
Panorama of congenital syphilis in school hospital of the hospital of the South region of city of São Paulo
}

\author{
Panorama da sífilis congênita em hospital escola do hospital da região sul da cidade
}

de São Paulo

Panorama de la sífilis congénita en el hospital escolar del hospital de la región sur de

la ciudad de São Paulo

\author{
Karina Bonilha Roque \\ ORCID: https://orcid.org/0000-0003-0349-3587 \\ Santo Amaro University, Brazil \\ E-mail: karinabonilha@yahoo.com.br \\ Bruna de Paula Alves \\ ORCID: https://orcid.org/0000-0002-6528-4847 \\ Santo Amaro University, Brazil \\ E-mail: brunap_alves@hotmail.com \\ Beatriz Félix da Silva \\ ORCID: https://orcid.org/0000-0002-3344-4340 \\ Santo Amaro University, Brazil \\ E-mail: bia.felix@me.com \\ Yára Juliano \\ ORCID https://orcid.org/0000-0002-8391-075X \\ Santo Amaro University, Brazil \\ E-mail: yjuliano@prof.unisa.br \\ Jefferson Carlos de Oliveira \\ ORCID https://orcid.org/0000-0002-5258-7099 \\ Anhanguera University Center of São Paulo, Brazil \\ E-mail: jeenf2007@hotmail.com \\ Jane de Eston Armond \\ ORCID https://orcid.org/0000-0003-1561-8113 \\ Santo Amaro University, Brazil \\ E-mail: jearmond@gmail.com
}

\begin{abstract}
Introduction: Congenital syphilis is an infectious disease that has the etiological agent Treponema pallidum. Its transmission is vertical hematogenous, transplacental, of infected pregnant untreated or inadequately treated for its concept. It divides into two periods: early to the second year of life, and after the second year of life, late. Detection during prenatal care is performed by screening the third trimester of pregnancy with preterm labor, as early as in the maternity ward. The detection of Treponema pallidum through non-treponemal test (VDRL), presents little specificity, high sensitivity, low cost and fast negativation in response to the treatment avoiding that the concept is born with sequels. Thus, prenatal care is an important tool in the control of the disease, and it is necessary to improve care quality, since $70 \%$ of the mothers in Brazil are prenatal, not all of them are diagnosed or have the appropriate treatment of syphilis. Objective: To establish an epidemiological panorama of the incidence of Congenital Syphilis in the socioeconomic and cultural context in which the School Hospital of the Southern Region of the city of São Paulo is inserted. Patients and Methods: This is an individualized, observational, cross-sectional study carried out by means of a medical records survey of the Hospital Infection Control Service of Hospital Escola da Região Sul in the city of São Paulo. The survey of data referring to the form with questions of interest to the mother and the newborns diagnosed with Congenital Syphilis in the period from 2012 to 2016 was developed. This project was submitted and approved by the Ethics Committee of the Santo Amaro University - SP (Plataforma Brasil - CAAE: 68103317.6.3001.5447). Results: A total of 183 cases of Congenital Syphilis were registered in the Hospital Infection Control Service of the São Paulo School Hospital from 2012 to 2016, and among these, 126 medical records were reinforced. Prenatal performance $(p=0.0060)$, schooling $(p=0.5107)$ and schooling $(p=0.8603)$ did not influence disease screening by showing insignificant statistical data. Success occurred with companion treatment $(p=0.0451)$, which showed the highest incidence in 2014 (48.1\%) and 2016 (58.3) when compared to the others. Conclusion: In the presented scenario, it was verified that although prenatal and maternal treatment were performed, they were inefficient to prevent pregnant women from transmitting the disease. This is probably related to the inefficiency of the
\end{abstract}


treatment of the companions, who although in the year 2014 and 2016 presented a higher incidence of accomplishment, coincided with the increase of notifications in those same years. There were no statistically significant differences in relation to other factores, a fact that causes concern in the field of Public Health.

Keywords: Congenital syphilis; Newborn at risk; Public health; Epidemiology.

\section{Resumo}

Introdução: a sífilis congênita é uma doença infecciosa que possui como agente etiológico Treponema pallidum. Sua transmissão é hematogênica vertical, transplacentária, de gestantes infectadas não tratadas ou tratadas inadequadamente para seu conceito. Divide-se em dois períodos: precoce até o segundo ano de vida e, após o segundo ano de vida, tardia. A detecção durante o pré-natal é realizada pela triagem do terceiro trimestre da gravidez com trabalho de parto prematuro, já na maternidade. A detecção do Treponema pallidum através do teste não treponêmico (VDRL), apresenta pouca especificidade, alta sensibilidade, baixo custo e rápida negativação em resposta ao tratamento evitando que o concepto nasça com sequelas. Assim, o pré-natal é uma ferramenta importante no controle da doença, sendo necessário melhorar a qualidade da assistência, visto que 70\% das mães no Brasil fazem o pré-natal, e nem todas têm diagnóstico de sífilis ou recebem o tratamento adequado. Objetivo: Traçar um panorama epidemiológico da incidência da Sífilis Congênita no contexto socioeconômico e cultural em que está inserido o Hospital Escola da Região Sul da cidade de São Paulo. Pacientes e Métodos: Trata-se de um estudo individualizado, observacional, transversal, realizado por meio de levantamento de prontuários do Serviço de Controle de Infecção Hospitalar do Hospital Escola da Região Sul da cidade de São Paulo. Foi desenvolvido o levantamento de dados referentes ao formulário com perguntas de interesse da mãe e dos recém-nascidos com diagnóstico de Sífilis Congênita no período de 2012 a 2016. Este projeto foi submetido e aprovado pelo Comitê de Ética da Universidade de Santo Amaro - SP (Plataforma Brasil - CAAE: 68103317.6.3001.5447). Resultados: No período de 2012 a 2016 , foram registrados 183 casos de Sífilis Congênita no Serviço de Controle de Infecção Hospitalar do Hospital Escola de São Paulo, sendo que destes, 126 prontuários foram reforçados. O desempenho pré-natal $(\mathrm{p}=0,0060)$, a escolaridade $(\mathrm{p}=0,5107)$ e a escolaridade $(\mathrm{p}=0,8603)$ não influenciaram o rastreamento da doença por apresentar dados estatísticos insignificantes. O sucesso ocorreu com o acompanhamento do acompanhante ( $\mathrm{p}=0,0451)$, que apresentou maior incidência em 2014 (48,1\%) e 2016 (58,3) quando comparado aos demais. Conclusão: No cenário apresentado, constatou-se que embora o pré-natal e o tratamento materno fossem realizados, eles eram ineficazes para evitar que as gestantes transmitissem a doença. Isso provavelmente está relacionado à ineficiência do tratamento dos acompanhantes, que embora no ano de 2014 e 2016 apresentassem maior incidência de cumprimento, coincidiu com o aumento das notificações nesses mesmos anos. Não houve diferenças estatisticamente significativas em relação aos outros fatores, fato que preocupa a Saúde Coletiva.

Palavras-chave: Sífilis congênita; Recém-nascido de risco; Saúde pública; Epidemiologia.

\section{Resumen}

Introducción: La sífilis congénita es una enfermedad infecciosa que tiene el agente etiológico Treponema pallidum. $\mathrm{Su}$ transmisión es hematógena vertical, transplacentaria, de embarazadas infectadas sin tratar o tratadas inadecuadamente para su concepto. Se divide en dos períodos: temprano hasta el segundo año de vida, y después del segundo año de vida, tardío. La detección durante la atención prenatal se realiza mediante la detección del tercer trimestre del embarazo con trabajo de parto prematuro, ya en la sala de maternidad. La detección de Treponema pallidum mediante prueba no treponémica (VDRL), presenta poca especificidad, alta sensibilidad, bajo costo y rápida negatividad en respuesta al tratamiento evitando que el concepto nazca con secuelas. Así, la atención prenatal es una herramienta importante en el control de la enfermedad, y es necesario mejorar la calidad de la atención, ya que el 70\% de las madres en Brasil son prenatales, no todas están diagnosticadas o tienen el tratamiento adecuado de sífilis. Objetivo: Establecer un panorama epidemiológico de la incidencia de la Sífilis Congénita en el contexto socioeconómico y cultural en el que se inserta el Hospital Escolar de la Región Sur de la ciudad de São Paulo. Pacientes y métodos: Se trata de un estudio individualizado, observacional, transversal, realizado mediante encuesta de historia clínica del Servicio de Control de Infecciones Hospitalarias del Hospital Escola da Região Sul de la ciudad de São Paulo. Se elaboró la encuesta de datos referentes al formulario con preguntas de interés para la madre y los recién nacidos diagnosticados con Sífilis Congénita en el período de 2012 a 2016. Este proyecto fue presentado y aprobado por el Comité de Ética de la Universidad Santo Amaro - SP (Plataforma Brasil - CAAE: 68103317.6.3001.5447). Resultados: Se registraron un total de 183 casos de Sífilis Congénita en el Servicio de Control de Infecciones Hospitalarias del Hospital Escolar de São Paulo de 2012 a 2016, de los cuales se reforzaron 126 historias clínicas. El rendimiento prenatal $(\mathrm{p}=0,0060)$, la escolaridad $(\mathrm{p}=0,5107)$ y la escolaridad $(\mathrm{p}=0,8603)$ no influyeron en el cribado de enfermedades al mostrar datos estadísticos insignificantes. El éxito se produjo con el tratamiento con acompañantes $(\mathrm{p}=0,0451)$, que mostró la mayor incidencia en $2014(48,1 \%)$ y $2016(58,3)$ en comparación con los demás. Conclusión: En el escenario presentado, se verificó que si bien se realizaron tratamientos prenatales y maternos, estos resultaron ineficientes para evitar que las embarazadas transmitieran la enfermedad. Esto probablemente esté relacionado con la ineficacia del trato de los acompañantes, que si bien en el año 2014 y 2016 presentaron una mayor incidencia de realización, coincidió con el aumento de notificaciones en esos mismos años. No 
hubo diferencias estadísticamente significativas en relación con otros factores, hecho que genera preocupación en el ámbito de la Salud Pública.

Palabras clave: Sífilis congénita; Recién nacido en riesgo; Salud pública; Epidemiologia.

\section{Introduction}

Congenital syphilis is an infectious disease whose etiologic agent is the bacterium Treponema pallidum. Its transmission is vertical and occurs via the hematogenic, transplacental route of infected pregnant untreated or inadequately treated for its concept. Congenital syphilis is divided into two periods: up to the second year of life, precocious, and after the second year of life, late (Brasil, 2017).

The WHO estimates the occurrence of more than one million cases of Sexually Transmitted Infections (STIs) per day worldwide. About 357 million new infections are reported per year, including chlamydia, gonorrhea, syphilis and trichomoniasis. Syphilis affects one million pregnant women worldwide each year, leading to more than 300,000 fetal and neonatal deaths and putting more than 200,000 children at risk of premature death. In Brazil, a constant increase in the number of cases of syphilis in pregnant women, both congenital and acquired, has been observed in the last five years, which can be attributed in part to the increase in the coverage of testing, with the expansion of the use of rapid tests, reduction of condom use, resistance of health professionals to the administration of penicillin in Primary Care, worldwide shortage of penicillin, among others. In addition, the enhancement of the surveillance system may be reflected in the increase in reported cases (Brasil, 2017).

The detection of Treponema pallidum can be done by means of a blood test (VDRL). It is characterized as a nontreponemal test, based on the cardiolopin antigen, has low specificity, high sensitivity, low cost, and rapid negativity in response to treatment, being therefore the most suitable for the tracing and cure control (Brasil, 2006).

It is important the early detection of congenital syphilis to treat the mother, thus preventing the concept from developing with sequelae. This early diagnosis is performed in the prenatal period, and it is recommended that the pregnancy be performed in the third trimester, with repetition prior to delivery, at the maternity hospital. Thus, prenatal care is an important tool in the elimination of congenital syphilis from the public health scenario, and it is necessary to improve the quality of care, as well as its expansion in the public system, since 70\% of mothers in Brazil attend the prenatal care, not all of them carry out adequate diagnosis or treatment. 2 In 2016, 87,593 cases of acquired syphilis were reported, 37,436 cases of syphilis in pregnant women and 20,474 cases of congenital syphilis - including 185 deaths - in Brazil. The highest proportion of cases was reported in the Southeast region (Brasil, 2017).

There are several public health policies aimed at reducing the incidence of congenital syphilis in Brazil. The compulsory notification, established in 1986, by the Epidemiological and Compulsory Disease Surveillance System, strategies for reducing vertical transmission of HIV (TVHIV) with the notification of pregnant women, parturients, HIV positive postpartum and exposed children, by the Department of STD, AIDS and Viral Hepatitis in the Pact for Health Plan "Operational Plan for the Vertical Transmission of HIV and Syphilis" in addition to the Family Health Strategy (ESF) (Secretaria de Estadual de São Paulo, 2009).

In view of the presented scenario, we chose to do this study in order to understand the high incidence of congenital syphilis in the socioeconomic and cultural context of the southern region of the city of São Paulo, specifically in the Grajaú General Hospital (HGG). For this, it is considered that syphilis is an avoidable disease, due to the possibility of being diagnosed and treated early, so that it can prevent the consequences and sequelae of the infected child.

The objective of this article is to establish an epidemiological panorama of the incidence of Congenital Syphilis in the socioeconomic and cultural context in which the School Hospital of the South Region of the city of São Paulo is inserted. 


\section{Methodology}

\subsection{Type of study}

It is an individual, observational, cross-sectional study whose instrument of study was a form for annotations of the variables of interest in relation to the mother and the newborn, collected in the medical records. The study has limitations due to the lack of refinement of the medical records data used (Pereira, 2018).

\subsection{Place of study}

Data collection was performed at the Hospital Infection Control Service of the Teaching Hospital of the southern region of the city of São Paulo.

\subsection{Population}

Included in this study were all newborns diagnosed with congenital syphilis and their respective mothers, between 2012 and 2016. The charts that did not present all the information required in the study were disregarded.

\subsection{Data collection and analysis}

The data collection complied with the form with variables of interest in relation to the mother and the newborns diagnosed with Congenital Syphilis between 2012 and 2016. This project was submitted and approved by the ethics committee of the Santo Amaro University (SP) Brazil - CAAE: 68103317.6.3001.5447). The chi-square test or Mann Fisher's exact test (Stiefel) was used to study the associations between the variables studied. The level of significance was set in the range of 0.05 or $5 \%$ (Siegel, 2006).

\section{Results}

A total of 183 cases of Congenital Syphilis were registered in the Hospital Infection Control Service of the Hospital School of the South Region of the city of São Paulo in the period from 2012 to 2016. Of these, 126 medical records were analyzed, in 2012, 31 registered cases, and 26 cases analyzed; in 2013, 35 cases registered, and 22 cases analyzed; in 2014, 37 cases registered, and 33 cases analyzed; in 2015, 36 cases registered, and 22 cases analyzed; in 2016, 44 cases registered, and 22 cases analyzed. The analyzed pregnant women presented the demographic characteristics related to the level of education represented in Table 1.

\begin{tabular}{|c|c|c|c|c|c|c|}
\hline Education level & 2012 & 2013 & 2014 & 2015 & 2016 & TOTAL (\%) \\
\hline Elementary School & 2 & 2 & 3 & 2 & 2 & 8,8 \\
\hline High school & 16 & 13 & 19 & 13 & 12 & 58,4 \\
\hline Higher education & 8 & 7 & 11 & 7 & 8 & 32,8 \\
\hline TOTAL & 26 & 22 & 33 & 22 & 22 & 100 \\
\hline
\end{tabular}

Source: Authors (2021).

The relationship between prenatal pregnancies diagnosed with congenital syphilis, as well as the number of 
consultations performed during prenatal care, are described in Tables 2 and 5, respectively.

\begin{tabular}{|c|c|c|c|c|}
\hline \multirow[b]{2}{*}{ Ano } & \multicolumn{2}{|c|}{ Prenatal care } & \multirow[b]{2}{*}{ TOTAL } & \multirow[b]{2}{*}{ \% Sim } \\
\hline & Sim & Não & & \\
\hline 2012 & 14 & 10 & 24 & 58,3 \\
\hline 2013 & 17 & 5 & 22 & 77,3 \\
\hline 2014 & 26 & 7 & 33 & 78,8 \\
\hline 2015 & 18 & 4 & 22 & 82,0 \\
\hline 2016 & 20 & 4 & 24 & 83,0 \\
\hline TOTAL & 95 & 30 & 125 & \\
\hline
\end{tabular}

Source: Authors (2021).

The relationship between maternal and companion treatment of the respective pregnant women diagnosed with Congenital Syphilis are described in Tables 3 and 5.

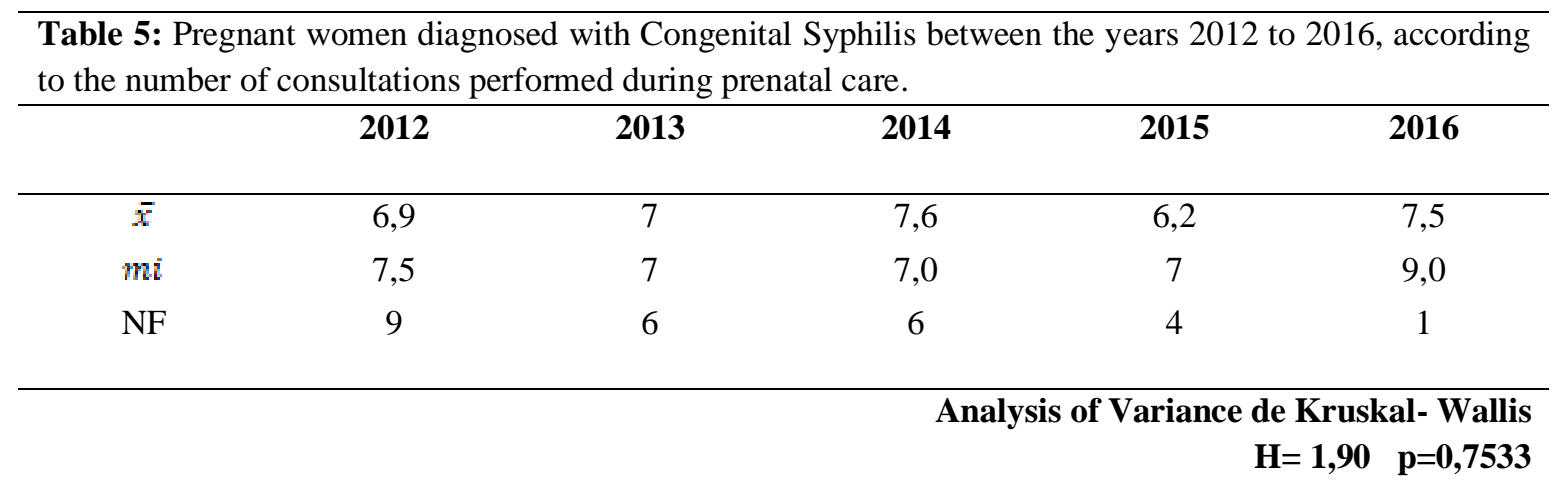

Source: Authors (2021).

The relationship between maternal and companion treatment of the respective pregnant women diagnosed with Congenital Syphilis are described in Tables 3 and 4.

\begin{tabular}{|c|c|c|c|c|}
\hline \multirow[b]{2}{*}{ Ano } & \multicolumn{2}{|c|}{ Maternal Treatment } & \multirow[b]{2}{*}{ TOTAL } & \multirow[b]{2}{*}{$\% \mathrm{Sim}$} \\
\hline & Sim & Não & & \\
\hline 2012 & 18 & 6 & 24 & 75,0 \\
\hline 2013 & 13 & 9 & 22 & 59,1 \\
\hline 2014 & 21 & 12 & 33 & 65,6 \\
\hline 2015 & 12 & 10 & 22 & 57,1 \\
\hline 2016 & 12 & 12 & 24 & 50,0 \\
\hline TOTAL & 76 & 49 & 125 & 60,0 \\
\hline
\end{tabular}

Source: Authors (2021).

The relationship between maternal and companion treatment of the respective pregnant women diagnosed with Congenital Syphilis are described in Table 4 . 
Table 4: Pregnant women diagnosed with Congenital Syphilis between the years 2012 to 2016, according to the accomplishment of the treatment of the companion.

\begin{tabular}{|c|c|c|c|c|}
\hline \multirow[b]{2}{*}{ Ano } & \multicolumn{2}{|c|}{ Companion Treatment } & \multirow[b]{2}{*}{ TOTAL } & \multirow[b]{2}{*}{$\% \mathrm{Sim}$} \\
\hline & Sim & Não & & \\
\hline 2012 & 5 & 19 & 24 & 20,8 \\
\hline 2013 & 8 & 14 & 22 & 36,2 \\
\hline 2014 & 13 & 20 & 33 & 39,4 \\
\hline 2015 & 5 & 17 & 22 & 22,7 \\
\hline 2016 & 14 & 10 & 24 & 58,3 \\
\hline TOTAL & 45 & 72 & 125 & 35,52 \\
\hline
\end{tabular}

The first minute Apgar variable presented data with no statistical significance when compared to all the cases recorded in all the evaluated years. $H=3.59(p=0.4680)$ and in the male $H=6.52(p=0.4680) . p=0.1634)$. As well as, in the fifth minute, female $\mathrm{H}=1.83(\mathrm{p}=0.7666)$ and male $\mathrm{H}=4.40(\mathrm{p}=0.3547)$.

The variable weight of the newborn also did not present significant statistical data, since the weights did not differ among the children with Congenital Syphilis born in the analyzed years, being $H=5,13(p=0,2737)$. In the years of 2012, 2013, 2014, 2015, 2016 the average weight was $2590.9 \mathrm{~g} ; 2668.2 \mathrm{~g} ; 2814.8 \mathrm{~g} ; 2911.7 ; 2788.6 \mathrm{~g}$, the median of 2635g; 2650g; $2852.5 \mathrm{~g} ; 2950 \mathrm{~g} ; 2755 \mathrm{~g}$, and the standard deviation of $514.2 ; 750.9 ; 797.2 ; 594.1 ; 598.9$, respectively.

The neonatal referral variable after hospital discharge to the Basic Health Unit or other health institutions also presented statistically insignificant data, with the chi-square test $\mathrm{X} 2=3.44(\mathrm{p}=0.4865)$.

\section{Discussion}

The variables educational level $(\mathrm{p}=0.8603)$, prenatal $(\mathrm{p}=0.3677)$ and maternal treatment $(\mathrm{p}=0.5107)$ didn't influence the disease screening by showing insignificant statistical informations. (Tables I, II and III, respectively)

The variable degree of maternal schooling when related to the incidence of Congenital Syphilis cases when establishing an insignificant correlation, means that the pregnant women analyzed had similar sociodemographic characteristics, most of them having a high school education (58.4\%), including in those who had incomplete and complete secondary education. This information corroborates the study of Domingues R.M.S.M. et al. of the study was born in Brazil, which revealed that the lower the education level of women, the higher the occurrence of syphilis and congenital syphilis infection, and an OR of 16.02 (95\% CI: 2.76-93.01) for incomplete elementary education in women with congenital syphilis outcome (Domingues, 2016). To this fact, one can also attribute the lack of knowledge about STD and the importance of correct prenatal care (Mazin; Mullick, 2004).

In another study, there was a higher incidence of pregnant women with syphilis in the age group between 20 and 29 years old, with schooling up to complete elementary school and black. This relation between syphilis with schooling, its more prevalent in elementary education (Zuzarte, 2020).

The insignificance of prenatal data $\left(\mathrm{X}^{2}=4.29 \mathrm{p}=0.3677\right)$ and the number of prenatal consultations $(\mathrm{H}=1.90 \mathrm{p}=$ 0.7533) for the screening and cases of Congenital Syphilis reflects the worrying panorama to which these pregnant women are exposed in this region. Since the lack of prenatal care has a significant relevance in relation to the persistence of high rates of congenital syphilis 7, as well as incomplete or inadequate performance, which includes lack of attendance or late onset (Domingues, 2013). 
In this study, although $76 \%$ of the mothers who had syphilis during pregnancy (Table II) had access to the health service at some time during pregnancy, it was not effective in the screening for Congenital Syphilis. Evidence that prenatal care may have been inadequately performed, since these mothers were not sensitized to attend all consultations. The number of consultations was also incipient, resulting in insignificant data (Table V), corroborating with the work of Starling SP in Syphilis in infants and Young children, in which it was verified that the inadequate prenatal prevents the accomplishment of the routine for the diagnosis of syphilis and its early intervention (Starling, 1994).

Regarding the maternal treatment for syphilis, there was also statistical insignificance $(\mathrm{X} 2=3.29 \mathrm{p}=0.5107)$, although $60 \%$ of the mothers stated that they underwent treatment (Table III). This can be attributed to non-compliance with preventive measures by health authorities and agents and self-medication. There may also be other factors that favor the chances of reinfection, such as lack of knowledge about the transmission of sexually transmitted infections (STDs), drug use, inadequate prenatal care, and maternal promiscuity (Peeling, 2004; Valderrama, 2005).

The lack of resources to carry out the treatment can also be a justification attributable to the indexes found, since there was a political transition during the years 2012 to 2016 in the region and in the city of São Paulo, which may have hampered the transfer of financial resources and physical.

The opposite occurred with companion treatment $(\mathrm{p}=0.0451)$, which had the highest incidence in $2014(48.1 \%)$ and 2016 (58.3) when compared to the others. (Table IV). However, these years were the ones that had the highest indexes of registered cases, 37 cases in 2014 and 44 cases in 2016, when compared with the other registries. This shows that the treatment of the companion was inefficient, since even with the highest rates of achievement in the years 2016 and 2014, there was a higher incidence of registered Congenital Syphilis cases.

According to the literature, the ineffective treatment of the partner is one of the determining factors for the success of the treatment for Congenital Syphilis, however, according to the Epidemiological Bulletin AIDS and STD, and the manual of epidemiological surveillance and assistance of Congenital Syphilis, the treatment of the partner is not successful due to the marital status of some carriers of the infection, with approximately $42 \%$ of the group being single. Other possible reasons are low schooling and / or non-acceptance of the partner in receiving treatment. The social question and the questioning of infidelity (multiplicity of partners) or the difficulty of approaching health professionals in the issues of sexuality related to STDs also make it difficult for the partners to join in the treatment of gestational syphilis (Brasil, 2006; Rodrigues, 2008).

In another study, the incidence of syphilis in pregnant and congenital women is closely proportional to the unfavorable socioeconomic structure of the countries, such as poverty, unemployment, little or no schooling, low coverage of prenatal care, is incident in underdeveloped and developed countries in the behavioral profile of unsafe sexual practices, promiscuity, alcohol and drug abuse (Ribeiro, 2020). This characteristics reflects the poor quality and performance of prenatal care in the country and / or the low importance that health professionals and mothers have directed to the diagnosis and treatment of syphilis during pregnancy, the absence of a fixed sexual partner and / or existence of multiple sexual partners, low levels of schooling, and limited access to health services (Oliveira, 2020; Araujo, 2006).

And so, since the main method of controlling syphilis transmission in communities is contact tracking and treatment, and serological testing and presumptive partner treatment are indispensable. Such practice could be improved by educational and interventional measures aimed at the prevention of congenital syphilis (Hawkes, 2011). This was proven in the study carried out by Lazarini e Barbosa, 2015, indicated that after changes and improvements in the diagnosis by the professionals, in the management of gestational syphilis, there was a reduction reduction in vertical transmission from educational interventions in primary care service in the city of Londrina, Paraná - Brazil (Lazarini, 2017).

Regarding the Apgar in the first minute of the children born with Congenital Syphilis, when related to type of delivery, cesarean or normal, did not present significant statistical difference; a fact that contradicts the literature, since, as 
pointed out in a study, Apgar at 1 minute indicated that children were born in better conditions when born from normal delivery compared to cesarean section, which is explained for cesarean referrals at the hospital to be performed based on risk factors for the mother or baby (Magalhães, 2011).

The weight of the infant with congenital syphilis in the present study was not statistically significant $(\mathrm{H}=5.13(\mathrm{p}=$ 0.2737), representing no direct correlation with complications of infection. This finding supports in literature, about of $70 \%$ of cases of early this disease are asymptomatic, however, the newborn may present prematurity, low weight, hepatosplenomegaly, skin lesions, periostitis, osteochondritis, jaundice, anemia, generalized lymphadenopathy, syndrome nephrotic, seizures, meningitis, thrombocytopenia, leukocytosis or leukopenia (Cooper, 2016).

However, this finding contradicts other studies that indicate that in untreated or inadequately treated syphilis, the rate of abortion or stillbirth is $25 \%$, prematurity or low birth weight, $13 \%$, neo-mortality, $11 \%$, and $20 \%$ of the infants are symptomatic. Thus, the infection may not directly interfere with the concept's weight gain, but it is a determining factor for postpartum complications (Cooper, 2016).

The non-significant statistic as to the forwarding of the newborn the Basic Health Unit or other institutions (X2 = 3.44 $\mathrm{p}=0.4865$ ) reflects an incorrect orientation, as recommended by the Ministry of Health are queries up to the 6th month of life and bi-monthly from the 6th month to the 12th month (Lazarini, 2017; Magalhães, 2011).

During the analysis of the medical records, a possible underreporting of Congenital Syphilis cases was also identified, due to lack of diligence in the medical records, as well as in the prenatal care booklet. It is observed that between 2007 and 2009 there was underreporting of gestational syphilis. From 2010 onwards an increase in the notification of the disease in pregnant women, however, vertical transmission remains high until 2013. In 2014 and 2015, after the educational intervention, there was a reduction in mother-to-child transmission rates for child by approximately $38 \%$, the educational intervention significantly increased the knowledge of health professionals about syphilis and helped to reduce the rate of vertical transmission of the grievance (Lazarini, 2017; Saraceni, 2017).

The results of the study when compared with other literature, corroborate that low socioeconomic conditions, absence or discontinuation of prenatal consultations of the pregnant woman and her partner, low education, inadequate diagnosis and treatment, lack of medication (benzathine penicillin), disqualified professionals and absence of compulsory notification, are relevant factors to decrease transmission to congenital syphilis. It is concluded that the active search, with screening of the population included in this research, must be carried out, working on new health education strategies and public policies to reach mainly pregnant women who are more vulnerable to this damage, reinforcing through guidance, lectures and discussion groups the importance of adhering to prenatal care and early treatment of infections sexually transmitted infections such as syphilis (Paiva, 2020). In this literature, the prevention and control strategies were: to improve syphilis tracking; invest in health professionals and expand prenatal coverage. Knowing and investigating the factors that influence the change in the profile of the infected population linked to government strategies to fight poverty and social vulnerability can contribute to greater adherence to treatment and bring responsible attitudes of STI prevention (Araujo, 2006).

The abortion item researched in the medical records was based on abortions carried out throughout the life, and for not having a direct correlation with the cases of Congenital Syphilis was discarded data.

\section{Conclusion}

In the presented scenario, it was verified that although prenatal and maternal treatment were performed, they were inefficient to prevent pregnant women from transmitting the disease. This is probably related to the inefficiency of the treatment of the companions, who although in the year 2014 and 2016 presented a higher incidence of accomplishment, 
coincided with the increase of notifications in those same years. There were no statistically significant differences in relation to maternal schooling and number of prenatal consultations, a fact that causes concern in the field of Public Health.

\section{References}

Araujo, E. C.; \& Gama, K. S.; Azevedo, R. S.; \& Gama, V. N. L.; \& Souto, F. A. (2006) The importance of prenatal care in the prevention of Congenital Syphilis. Rev. Paraense de Medicina.

Brasil. (2017). Ministério da Saúde. Secretaria de Vigilância em Saúde. Boletim Epidemiológico. 48 (36).

Brasil. Ministério da Saúde. (2006). Diretrizes para controle da sífilis congênita: manual de bolso, Secretaria de Vigilância em Saúde, Manuais Programa Nacional de DST/Aids. https://bvsms.saude.gov.br/bvs/publicacoes/manual_sifilis_bolso.pdf.

Cooper, J. M.; \& Michelowb, I. C.; \& Wozniaka, S. P.; \& Sanchez, P. J. (2016) In time: the persistence of congenital syphilis in Brazil. Revista Paulista de Pediatria. Rev. paul. pediatr. 34(3). São Paulo July/Sept. http://dx.doi.org/10.1016/j.rppede.2016.06.004.

Domingues, R. M. S. M., \& Leal, M.C. (2016). Incidence of congenital syphilis and factors associated with vertical transmission: data from the Birth in Brazil study. Cad.Saúde Pública, 32 (6), e00082415. https://doi.org/10.1590/0102-311X00082415.

Domingues, R. M. S. M., \& Saracen, V., \& Hartz, Z. M. A., \& Leal, M. C. (2013). Congenital syphilis: a sentinel event in antenatal care quality. Rev. Saúde Pública, 47 (1), 147-157. https://www.scielo.br/scielo.php?script=sci_arttext\&pid=S0034-89102013000100019.

Hawkes, S; \& Matin, N.; \& Broutet, N.; \& Low, N. Effectiveness of interventions to improve screening for syphilis in pregnancy: a systematic review and meta-analysis. (2011) Lancet Infect Dis 11(9):684-91. http://dx.doi. org/10.1016/S1473-099(11)70104-9.

Lazarini, F. M.; \& Barbosa, D.A. Intervenção educacional na Atenção Básica para prevenção da sífilis congênita. (2017). Revista Latino-Americana De Enfermagem, 25, e2845-. https://doi.org/10.1590/1518-8345.1612.2845.

Magalhães, D. M. S.; \& Kawaguchi, I. A. L.; \& Dias, A.; \& Calderon, I. M. (2011) Siphylis in pregnancy and their influence on fetal and maternal morbidity. Com. Ciências Saúde. S43-S54, 2011.

Mazin, R., \& Zacarías, F., \& Valderrama, J. (2004). Maternal syphilis and congenital syphilis in Latin America: big problem, simple solution. Rev Panam Salud Publica, 16 (3), 211-217. https://www.scielosp.org/article/rpsp/2004.v16n3/211-217/.

Mullick, S., \& Broutet, N., \& Htun, T., \& Temmerman, M., Ndowa. (2004). Bulletin of the World Health Organization, 82 (6), 431-432. https://www.scielosp.org/article/bwho/2004.v82n6/431-432/.

Oliveira, V. S.; \& Rodrigues, R. L.; \& Chaves, V. B.; \& Santos, T. S.; \& De Assis, F. M.; \& Ternes, Y. M. F.; \& Aquino, E. C. (2020) Aglomerados de alto risco e tendência temporal da sífilis congênita no Brasil. Rev Panam Salud Publica.; 44:e75. https://doi.org/10.26633/RPSP.2020.75.

Paiva, M. R. R., \& Silva, R. C. S., \& Olivindo, D. D. F. (2020). Congenital syphilis in Brazil: a reality to be faced, 9 (10), e7990109258. http://dx.doi.org/10.33448/rsd-v9i10.9258.

Peeling, R. W., \& Ye, H. (2004). Diagnostic tools for preventing and managing maternal and congenital syphilis: an overview. Bulletin of the World Health Organization, 82(6), 439-446.

Pereira, A. S. et al. (2018). Metodologia da pesquisa científica. UFSM. Htps://repositório.ufsm.br/bitstream/handle/1/15824/Lic_Computacao_MetodologiaPesquisa-Ciencia.pdf?sequence

Ribeiro, R. S., \& Segura, G. S., \& Ferreira A. C. M., \& Sasaki, N. S. G. M. S., \& Santos, M. L. S. G., \& Vendramini, S. H. F. (2020). Epidemiology of gestational and congenital syphilis: integrative literature review, 9 (4) e178942470. https://rsdjournal.org/index.php/rsd/article/view/2470/2727. http://dx.doi.org/10.33448/rsd-v9i4.2470.

Rodrigues, C. S., \& Guimarães, M. D. C., \& César, C. C. (2008). Missed opportunities for congenital syphilis and HIV perinatal transmission prevention. Revista de Saúde Pública, 42(5), 851-858. https://dx.doi.org/10.1590/S0034-89102008000500010.

Saraceni, V.; \& Pereira, G. F. M.; \& Silveira, M. F.; \& Araujo, M. A. L.; \& Miranda, A. E. (2017) Vigilância epidemiológica da transmissão vertical da sífilis: dados de seis unidades federativas no Brasil. Rev Panam Salud Publica. 41:e44. 10.26633/RPSP.2017.44.

$\begin{array}{llllllllll}\text { Secretaria de } & \text { Estadual de } & \text { São } & \text { Paulo } & \text { (2009). Programa } & \text { Estadual } & \text { DST/Aids }\end{array}$ http://www3.crt.saude.sp.gov.br/iec/pe_dst_aids_sp_portugues.pdf.

Siegel, S., \& Castellan, Jr, N. J. (2006). Estatística não paramétrica para ciências do comportamento. Segunda edição. Artmed.

Starling S. P. (1994). Syphilis in infants and young children. Pediatric annals, 23(7), 334-340. https://doi.org/10.3928/0090-4481-19940701-06.

Valderrama, J., \& Urquia Bautista, A., \& Orlich, G., \& Siri, R. S., \& Luz Osimani, M., \& Abreu, H., \& Messano, L. C., \& Pedre ira, W., \& Braselli, A., \& Fonseca, M. G.M., \& Matida, L. H., \& Saraceni, V., \& Pinto, V., \& de Oliveira, E. C., \& Kamb, M. L., \& Almanzar, A., \& Hernandez, Y. (2005). Maternal and congenital syphilis: case definitions. Epidemiological bulletin, 26(1), 12-15.

Zuzarte, J. S., \& Santos, I. M. M., \& Silva, A. S., \& Silva, L. C. O., \& Santos, V. F., Rebello, P. D. (2020). Profile of pregnant women with syphilis in public maternity, 9 (11), e46091110106. http://dx.doi.org/10.33448/rsd-v9i11.10106. 